\title{
The Influence of Morphological Characteristics on Throw Speed in Handball
}

\author{
Novica Gardašević a ${ }^{\star}{ }^{\star}\left(\mathbb{D}\right.$, Dalibor Fulurija ${ }^{b}$, Marko Joksimović ${ }^{\mathbb{C}}$, \\ Nebahat Eler ${ }^{d}$, Farruh Shavkatovich Ahmedov ${ }^{e}$ \\ a Elementary school Dobrislav Đ. Perunović, Nikšić, Montenegro \\ ${ }^{b}$ Faculty of Sport and Physical Education, University of East Sarajevo, Bosnia and Herzegovina \\ c Football club National, Podgorica, Montenegro \\ d Department of Physical Education and Sports, Bulent Ecevit University, Zonguldak, Turkey \\ e Samarkand State University, Uzbekistan \\ *Corresponding author Email: nicifor007@outlook.com \\ DOI: https://doi.org/10.34256/ijpefs2035 \\ Received: 03-07-2020, Revised: 19-08-2020; Accepted: 10-09-2020; Published: 22-09-2020
}

\begin{abstract}
The diagnosis of morphological characteristics is an integral part of the entire training process in sports. This study aimed to determine the influence of morphological characteristics on the ball's speed of movement after the shoot from a spot and movement in handball. The sample included 36 female handball players aged 14.33 years. The predictor set consisted of 10 morphological variables. In comparison, the three variables constituted the criterion variables by which the ball's speed of movement was determined after different ways of shooting. Using regression analysis, it was found that the predictor set of variables explains about $70 \%$ of the variance for all three criterion variables. Individually, a statistically significant and positive influence on the speed of movement of the ball after the shot was recorded at the height and weight of the body, while a negative effect was observed for the variables; arm length, leg length and skin fold on the abdomen. Based on the results obtained, it can be concluded that morphological characteristics significantly influence the speed of movement of the ball after a shot in the handball, which can significantly contribute to the selection of handball players, as well as in establishing the tactics of handball, especially in situations where one shot decides the match. Also, the obtained results indicate the necessity of considering the age characteristics of the female respondents, that is, the need to adjust the training process to the period of intensive growth and development.
\end{abstract}

Keywords: Body kinematics, levers, elevation angle, quasi-cyclical movements.

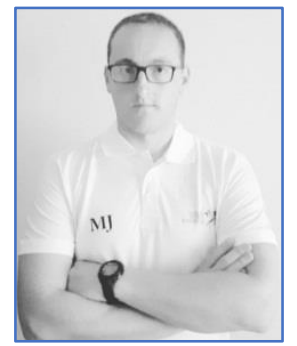

Joksimović Marko completed his MSc studies at the Faculty of Physical Education and Sports, University of East Sarajevo. Currently, he is working as a sports scientist at the GSF diagnostic center in Serbia. He is working in the National football club in Montenegro, in the position of strength and conditioning coach. His research interests focus on Soccer, Exercise physiology, sports and rehabilitation science, biomechanics, strength and conditioning.

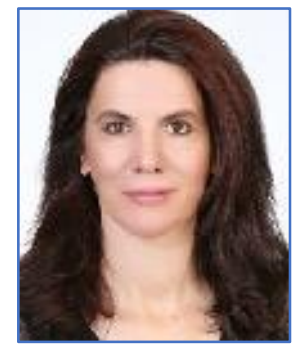

Dr. Nebahat Eler graduated from Gazi Nebahat Eler graduated from Gazi University Faculty of Education, Physical Education and Sports Department in 1993. She completed her Master's Degree program in 1996 and Doctorate Program in 2013 at Gazi University Health Sciences Institute.Currently, she works as the Head of the Department of Coaching Education and Head of the Department of Sports and Health Sciences at Zonguldak Bülent Ecevit University School of Physical Education and Sports. She is a member of the Canoe Federation Scientific Board. Her areas of specialization are Training, Physical Education and Sport, Fitness, Anthropometry, Volleyball and Handball. 


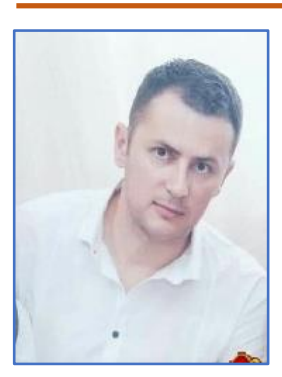

Gardašević Novica is a Ph.D. Scholar of the Faculty of Physical Education and Sports, University of East Sarajevo -Bosnia and Herzegovina. He also serves as a physical education lecturer in a primary school for the past seven years and ten years as a coach in the universal school of sports "TALENT" with children aged between 4 to 10 . $\mathrm{He}$ is a licensed person to perform sports and recreational activities in Montenegro.

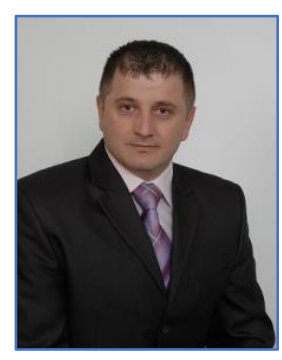

Dr. Dalibor Fulurija is a full professor at the University of East Sarajevo, Faculty of Physical Education and Sports. His current research includes exercise and sports science, strength and conditioning and sports medicine.

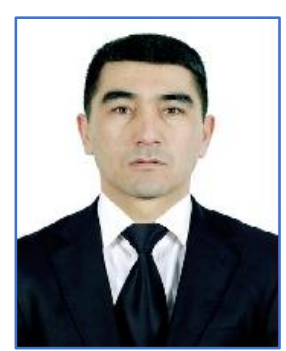

Farruh Shavkatovich Ahmedov is a Ph.D. student at Samarkand State University, Faculty of Physical Education. Teacher of the qualification and retraining institute of Samarkand branch. He also serves as a Scientific Committee Member of the Kurash Federation of Uzbekistan (KFUz) and acts as an official referee of the Judo Federation of Uzbekistan (JFUz).

\section{Introduction}

Morphological characteristics, as an integral part of human anthropological status, occupy a significant place in selecting and identifying talents for successful sports. Studying the morphological characteristics, their influence and relations on the success in sports is an indispensable process that should better complete the equation of specification for a particular sport and thus contribute to an adequate athlete modeling. If we spontaneously involve children in sports and make the selection according to the closest sports club or parents' wishes, the result will be absent. Gardašević, Terzić, [1] states that modern technological advances enable fast and accurate analysis of tested data in sports based on which errors in practical work can be corrected. Smaller adjustments can be made in a shorter period, while more extensive adjustments require longer processes. The preceding points to the constant need to monitor the impact of the anthropological status segment on athletic achievement and the effects of the training and competitive process on athletes' anthropological status. The influence and correlation of morphological characteristics on success in handball have been addressed by researchers in scientific studies [2-7]. Research has shown that physical and physiological abilities, as well as the performance of handball players, are, to some extent, influenced by morphological (anthropometric) characteristics [8]. Handball is a typical team sports game characterized by the correlation between each player's performance and team performance and the performance of the opponent and the opposing team [9]. A handball game aims to score more goals than your opponent and score the difference between goals scored and goals received. It depends on several factors (predictable and unpredictable) whether the ball ends up in the opponent's goal net after the shot. Indeed, the ball's speed directed towards the opponent's goal is a crucial factor for scoring. The shot that caused the ball to move quickly towards the opponent's goal would certainly be challenging when defending the goalkeeper's opponent. The speed of movement of the ball influences the inability of the goalkeeper to respond adequately, which mainly results in the ball ending up in the net. The speed of movement of the ball after the shot has been analyzed in some studies to date. Rogulj et al., [10] found that the speed of movement of the ball significantly depends on motor efficiency and that explosive power in the form of throw-in plays a dominant role. Serrien et al., [11] found differences in ball throw in velocity between handball players and female handball players. They defined that kinematic parameters of the pelvis, torso, shoulders and elbow play an important role in ball ejection velocity. The aforementioned authors also point to the need for additional research to determine the clearer association and influence between handball players' anthropometric profile and the speed of movement of the ball in handball. Accordingly, the current research aims to determine the influence of morphological characteristics on the ball's speed of movement after the shot from the spot and the movement of the female cadet handball players.

\section{Methods}

\subsection{Sample of subjects}

Sixteen late-adolescent male basketball players (with the study was conducted on a sample of 36 female handball players, ŽRK Trebjesa from Nikšić, 
mean chronological age (Mean \pm Std.Dev.) $(14.33 \pm 0.57)$, Body height $(169.12 \pm 6.00 \mathrm{~cm})$, Body Weight $(60.13 \pm 8.60 \mathrm{~kg})$, Body Mass Index $\left(20.91 \pm 2.51 \mathrm{~kg} / \mathrm{m}^{2}\right)$. The testing was carried out at the Sports and Recreation Center in Niksic. The research was carried out with the consent of the parents of the handball players who gave their written consent and the coach and management of the club.

\subsection{Sample of measures}

The set of variables applied was divided into predictor variables (morphological) and 3 criterion variables that related to the estimation of the speed of movement of the ball after the shot. All anthropometric variables (Body Height (BH), Body Weight (BW), Arm Length (AL), Leg Length (LL), Shoulder Width (SW), Fist Width (FW), Foot Width (FoW), Upper arm circumference (UAC), Lower leg circumference (LLC), Abdominal Skinfold Volume ASV)) were measured according to International Society for the Advancement of Kinanthropometry (ISAK) standard procedures. Marfell-Jones, et al., [12]. Anthropometer, caliper, and measuring tape were used for morphological measurements. Three criterion variables were used to estimate the ball throw in speed: $7 \mathrm{~m}$ shot (BS7M), two-step 9m shot (BS9MD) and jump 9-meter shot (BS9MJ). The speed of movement of the ball was measured by the radar gun Speedster Radar Gun of the American manufacturer " Bushnell ". The radar gun used for the purposes of this research has also been used in similar studies to determine the speed of ball movement $[10,13,14]$. The radar gun was positioned behind the goal, at a distance of $100 \mathrm{~cm}$ from the goal structure, at the height of $150 \mathrm{~cm}$ from the ground. It was kicked with standard handball number 2 (54-56 $\mathrm{cm}$ - 325-375 g.), which is under the applicable handball rules for the age of female cadets (www.zrsizp.rh) [15]. Goal kicking was realized after the warm-up exercises.

\subsection{Aerobic Power Test -Shuttle Run Test of 20 Meter}

The test has been shown to be a reliable and valid All data collected through the survey were processed by the methods of descriptive and comparative statistics. From the area of descriptive statistics, measures of central tendency and measures of dispersion of results were made. The influence of predictor variables on the criterion variables was determined using comparative statistics-regression analysis. The statistical program for personal computers SPSS for Windows version 20.0 was applied for data processing.

\section{Results}

The results of the descriptive statistics of all applied variables in the survey are shown in Table 1. Analyzing the level of statistical significance for the Kolmogorov-Smirnov test, it can be concluded that there is no statistically significant disturbance of the normal distribution of the results, which indicates that the results are reliable and can be used for further analysis.

The results of the regression analysis related to the influence of the predictor set of morphological variables on the criterion variable of ball speed after a seven-meter shot (BS7M) are shown in Table 2. At the overall level, a statistically significant influence of morphological characteristics on the stated criterion was determined. The multiple correlation coefficient $R$ $=0.83$, confirms the high level of prediction of the dependent variable. The coefficient of determination $\mathrm{R}^{2}=0.70$ indicates that the predictor set of variables explains $70 \%$ of the variance of the criterion variable. Only $30 \%$ of the variability of the criteria can be attributed to some other anthropological abilities and characteristics of the female respondents.

Similar results were obtained in Table 3, where the multiple correlation coefficient $\mathrm{R}=0.83$ confirms the high level of prediction of the dependent variable. In contrast, the determination coefficient $\mathrm{R}^{2}=0.69$ indicates that the predictor variable set explains $69 \%$ of the variance of the criterion variable ball speed after two-step $9 \mathrm{~m}$ shot (BS9MD).

Analyzing the results of the influence of morphological characteristics on the speed of movement of the ball after the jump shot from 9 meters in Table 4, we found similar results as in the previous two cases. The coefficient of determination $\mathrm{R}^{2}$ $=0.70$ indicates that the predictor set of variables explains $70 \%$ of the variance of the criterion variable (BS9MJ). A partial and positive influence on the criterion variable was found in the variable body height, while the variables had a negative impact; arm length, leg length and skin fold on the abdomen.

\section{Discussion}

The study aimed to determine the influence of morphological characteristics on the speed of the ball after the shot from the spot and the movement of the female cadet handball players. 
Table 1 Descriptive parameters

\begin{tabular}{|c|c|c|c|c|c|c|c|c|c|}
\hline \multicolumn{5}{|c|}{ Anthropometric parameters } & \multicolumn{5}{|c|}{ Ball speed } \\
\hline $\begin{array}{c}\text { Variabl } \\
\text { es }\end{array}$ & Mean & $\begin{array}{c}\text { Std.Dev } \\
.\end{array}$ & Range & KS-p & Variables & Mean & Std.Dev. & Range & KS-p \\
\hline $\mathrm{BH}$ & 169.12 & 6.00 & 22.90 & 0.65 & BS7M & 63.13 & 9.59 & 32.00 & 0.31 \\
\hline BW & 60.13 & 8.60 & 33.10 & 0.29 & BS9MD & 67.80 & 10.36 & 32.00 & 0.79 \\
\hline $\mathrm{AL}$ & 74.14 & 4.85 & 16.70 & 0.31 & BS9MJ & 69.05 & 8.79 & 34.00 & 0.32 \\
\hline $\mathrm{LL}$ & 95.11 & 5.54 & 21.10 & 0.21 & & & & & \\
\hline SW & 35.68 & 1.54 & 6.00 & 0.44 & & & & & \\
\hline FW & 7.79 & 0.37 & 1.50 & 0.66 & & & & & \\
\hline FoW & 9.31 & 0.56 & 2.00 & 0.20 & & & & & \\
\hline UAC & 25.66 & 1.96 & 8.20 & 0.08 & & & & & \\
\hline LLC & 51.21 & 7.27 & 29.50 & 0.44 & & & & & \\
\hline ASV & 17.77 & 9.24 & 33.00 & 0.08 & & & & & \\
\hline
\end{tabular}

Table 2 Regression analysis of morphological characteristics and criterion variable $7 \mathrm{~m}$ shot (BS7M)

\begin{tabular}{|c|c|c|c|c|c|}
\hline \multirow[t]{2}{*}{ Model } & \multicolumn{2}{|c|}{$\begin{array}{l}\text { Unstandar. } \\
\text { Coefficients }\end{array}$} & $\begin{array}{c}\text { Standard. } \\
\text { Coefficients }\end{array}$ & \multirow[t]{2}{*}{$\mathrm{t}$} & \multirow[t]{2}{*}{$P$} \\
\hline & $B$ & $\begin{array}{l}\text { Std. } \\
\text { Error }\end{array}$ & Beta & & \\
\hline (Constant) & 98,145 & 72,592 & & 1,352 & , 188 \\
\hline BH & 2,093 & 860 & 1,311 & 2,435 & 022 \\
\hline $\mathbf{A L}$ & $-2,440$ & 804 & $-1,235$ & $-3,037$ & ,006 \\
\hline LL & $-1,810$ & 558 & $-1,046$ & $-3,241$ & 003 \\
\hline SW & 1,319 & 1,759 & 213 & 750 & 460 \\
\hline FW & $-7,521$ & 7,591 &,- 296 & -991 & 331 \\
\hline FoW & 2,997 & 4,080 & 177 & ,735 & 469 \\
\hline BW & 1,296 & 830 & 1,163 & 1,561 & 131 \\
\hline UAC & $-4,218$ & 3,676 &,- 864 & $-1,148$ & 262 \\
\hline LLC &,- 146 & 177 &,- 111 &,- 825 & 417 \\
\hline ASV &,- 832 & 316 &,- 739 & $-2,633$ & 014 \\
\hline \multicolumn{6}{|c|}{$R=0,83 \quad R^{2}=0,70 \quad F=5,86 \quad p=0,00$} \\
\hline
\end{tabular}

Table 3 Regression analysis of morphological characteristics and criterion variables of two -step $9 \mathrm{~m}$ shot on goal. (BS9MD)

\begin{tabular}{|c|c|c|c|c|c|}
\hline \multirow[t]{2}{*}{ Model } & \multicolumn{2}{|c|}{$\begin{array}{l}\text { Unstandard. } \\
\text { Coefficients }\end{array}$} & \multirow{2}{*}{$\begin{array}{c}\text { Standard. } \\
\text { Coefficients } \\
\text { Beta }\end{array}$} & \multirow[t]{2}{*}{$\mathrm{t}$} & \multirow[t]{2}{*}{ Sig. } \\
\hline & $B$ & Std. Error & & & \\
\hline (Constant) & 134,410 & 79,306 & & 1,695 & ,103 \\
\hline $\mathrm{BH}$ & 1,418 & , 939 & ,822 & 1,510 & 144 \\
\hline $\mathbf{A L}$ & $-1,913$ & 878 &,- 896 & $-2,180$ &, 039 \\
\hline LL & $-1,623$ &, 610 &,- 867 & $-2,660$ &, 013 \\
\hline SW & 3,349 & 1,921 & ,500 & 1,743 & ,094 \\
\hline FW & $-16,770$ & 8,293 &,- 611 & $-2,022$ & ,074 \\
\hline FoW & 4,832 & 4,457 & ,264 & 1,084 & 289 \\
\hline BH & 2,177 & ,907 & 1,808 & 2,401 &, 024 \\
\hline UAC & $-5,580$ & 4,016 & $-1,057$ & $-1,390$ & 177 \\
\hline LLC & -179 & ,194 &,- 126 &,- 924 & 365 \\
\hline ASV & $-1,294$ & ,345 & $-1,064$ & $-3,749$ &, 001 \\
\hline \multicolumn{6}{|c|}{$R=0,83 \quad R^{2}=0,69$} \\
\hline
\end{tabular}


Table 4 Regression analysis of morphological characteristics and criterion variables 3 step jump shot from $9 \mathrm{~m}$ (BS9MJ)

\begin{tabular}{|c|c|c|c|c|c|}
\hline \multirow[t]{2}{*}{ Model } & \multicolumn{2}{|c|}{$\begin{array}{l}\text { Unstandard. } \\
\text { Coefficients }\end{array}$} & $\begin{array}{c}\text { Standard. } \\
\text { Coefficients }\end{array}$ & \multirow[t]{2}{*}{$\mathrm{t}$} & \multirow[t]{2}{*}{ Sig. } \\
\hline & $B$ & Std. Error & Beta & & \\
\hline (Constant) & $-52,932$ & 65,674 & &,- 806 & 428 \\
\hline $\mathrm{BH}$ & 1,978 & ,778 & 1,351 & 2,544 & 018 \\
\hline $\mathbf{A L}$ & $-1,464$ & ,727 &,- 807 & $-2,013$ & ,050 \\
\hline LL &,- 637 & ,505 &,- 401 & $-1,260$ & 219 \\
\hline SW & 268 & 1,591 & ,047 & , 168 & 868 \\
\hline FW & $-8,755$ & 6,868 &,- 376 & $-1,275$ & 214 \\
\hline FoW & $-3,203$ & 3,691 &,- 206 &,- 868 & ,394 \\
\hline BH & 166 & ,751 & 163 & 222 & 826 \\
\hline UAC & 2,424 & 3,325 &, 541 & ,729 & 473 \\
\hline LLC &,- 152 & 160 &,- 125 &,- 946 &, 353 \\
\hline ASV & $-1,114$ & ,286 & $-1,079$ & $-3,897$ &, 001 \\
\hline \multicolumn{3}{|c|}{$R=0,84 \quad R^{2}=0,70$} & $=6,08 p$ & 00 & \\
\hline
\end{tabular}

Analyzing the descriptive parameters of the criterion variables in Table 1, it can be concluded that the handball players achieved the best result at 9 meters three-step jump shot, a slightly worse result from a shot from 9 meters after a two-step, and the worst result when shooting from a place, or when the performance of the $7 \mathrm{~m}$ penalty shot. In a study conducted by Rogulj et al., [10], on a sample of students aged 19 to 21 , it was found that the respondents achieved better results in the speed of the ball when shooting from the ground, while the results when jumping shot were worse.

The explanation in the difference of the obtained results can certainly be multifaceted, and above all it can refer to the specificity of gender, age, but also in the efficiency of performing technical elements when performing the said shots. Analyzing the partial influences of the predictor variables on the criterion of Tables 2, a positive influence of body height was found, while arm length, leg length, and skin fold on the abdomen had a negative effect on the speed of movement of the ball during a $7 \mathrm{~m}$ shot. The reasons for the negative influence of the variables arm length and leg length on the speed of the ball when performing the $7 \mathrm{~m}$ shot can be found in the age characteristics of the subjects, that is, in the period of their rapid growth and development in which they were during the time of the test. At the age of the respondents (14.33 years), the increase in body height begins to increase rapidly, especially at the expense of elongation. According to Kurelić et al., [16], the annual increase in body height in girls between the ages of 13 and 15 is slightly less than $4 \mathrm{~cm}$, and the increase in body weight is about $3 \mathrm{~kg}$. As body height increases, so does body weight. Extremities are elongated, though their size depends on the constitutional type. In the leptosomatic type, they are longer than in the athletic and pyknic ones. As body growth in width and trunk growth lag behind limb growth, girls get a tall and protruding appearance.

According to the above, the muscles during such intensive development do not follow the uniform growth of the skeleton, which causes impaired coordination, so the negative influence of limb length on the speed of the ball in the respondents can be attributed to the above characteristics of age, probably impaired coordination and, consequently, worse technical performance of the hand elements. Analyzing the partial effects of Tables 3, the results were obtained, where body height had no statistical significance on the criterion variable. At the same time, bodyweight positively influenced the result when testing the speed of movement of the ball after a twostep $9 \mathrm{~m}$ shot. The abdominal skin fold variable negatively affected the analyzed criterion variable. The positive influence of body height and weight on the speed of the ball after a shot in the handball, as well as the negative influence of the subcutaneous fatty tissue, suggests that taller handball players, whose weight is not caused by excessive subcutaneous fat, belong to the more developed subjects who, when kicking, have the possibility of a stronger throw of the ball. According to Rogulj et al., [10] the speed of the ball, in addition to anthropological parameters, depends on the length of the path on which the body acts on the ball during the throwing movement, the 
amount of musculature involved, as well as the rate of concordance and relaxation of the muscles involved in the throw of the ball. Based on the analysis of modern handball and the testing of a number of handball players of different ages and quality levels, it can be stated with great certainty that this sport requires a high level of tendencies for height and weight gain. On average, handball players are lower than basketball players and volleyball players only, while outside players and goalkeepers are highest according to player positions, and wing players are the lowest. The arm span is approximately $10 \mathrm{~cm}$ larger than the height of the body, and this feature is most important, especially for the wing and outside players, due to the more successful and faster shot [17]. Subcutaneous tissue, measured indirectly through the skin fold on the abdomen, proved to be an unfavorable factor in the expression of explosive power through the handball shots, through which the speed of movement of the ball was estimated. Subcutaneous tissue is ballast mass which, according to the degree of accumulation in certain parts of the body, adversely affects movement, which further causes worse motor and specific-motor skills in the sport. According to Mcleod et al., [18], excess adipose tissue acts as a "dead" weight. In contrast, according to Gabbet, [19] adipose tissue has an inverse relationship, ie a negative influence with aerobic capacity and thermoregulation.

\section{Conclusions}

The analysis of morphological characteristics and their importance in sports is a continuous process that aims to contribute to better selection, improvement of the training process and ultimately to achieving the highest results and preserving the health status of athletes. Based on the results obtained by regression analysis, it was found that the morphological characteristics had a statistically significant influence on the criterion variables related to the speed of movement of the ball in handball in different types of shots. The set of variables applied explains about $70 \%$ of the variance of the criterion variables, which indicates the importance of adequate selection in women's handball. Also, the negative impact of arm's length and leg length on the analyzed criteria indicates the need to consider the age characteristics of athletes, ie the need to adapt the training process to the sensitive stages of child development, to adequately accompany the accelerated level in terms of preventive action on deformities and then in terms of more detailed work to develop coordination and improve technique.
Subcutaneous adipose tissue, confirmed in this research, requires special attention in working with children to prevent through sedentary lifestyle and the onset of obesity through physical activity. Generally speaking, the results obtained have multiple applications, both in terms of selection, the need to adjust the training process to the age, and in terms of deciding coaches when setting tactical solutions at the game, selecting $7 \mathrm{~m}$ penalty shooters, shooting at the end of attack time and more.

\section{References}

[1] I. Terzić, B. Gardašević, Relations of constitutional characteristics and motoric abilities of Serbia and Montenefro and Montenegro, Sport Mont, 9 (2011) 69-75.

[2] S. Jaric, S, D. Ugarkovic, M. Kukolj, Anthropometric, strength, power and flexibility variables in elite male athletes: Basketball, handball, soccer and volleyball players, Journal of Human Movement Studies, 40 (2001) 453464.

[3] D. Hatzimanouil, N. Oxizoglou, Evaluation of the morphological characteristics and motor skills in the national junior handball teams of Greece and Yugoslavia, Journal of Human Movement Studies, 46 (2004) 125-140.

[4] H. Mohamed, R. Vaeyens, S. Matthys, M. Multael, J. Lefevre, M. Lenoir, R. Philippaerts, Anthropometric and performance measures for the development of a talent detection and identification model in youth handball, Journal of Sports Sciences, 27 (2009) 257-266. https://doi.org/10.1080/02640410802482417

[5] S. Karišik, S. Goranović, Z. Valdevit, Mogućnost selekcije vrhunskih rukometaša u zavisnosti od antropometrijskih karakteristika. [In Serbian]. Sport i zdravlje, 6 (2011) 60-66.

[6] B. Gardašević, I. Terzić, Pokazatelji situacione efikasnosti na Šampionatu Evrope u rukometu za Žene 2010. [In Serbian], Sport Mont, 9 (2011) 231-237.

[7] V. Stanković, J. Malacko, I. Bojić, J. Ilić, Relations between morphological variables and normal and pathological conative characteristics of handball players, SportLogia, 9(2) (2013) 8999.

http://dx.doi.org/10.5550/sgia.130902.en.004S

[8] A. Chaouachi, M. Brughelli, G. Levin, N.B. Boudhina, J. Cronin, K. Chamar, Anthropometric, physiological and performance characteristics of 
elite lean handball players, Journal of Sports Science, 27 (2009) 151-157.

https://doi.org/10.1080/02640410802448731

[9] L. T. Ronglan, T. Raastad, A. Borgesen, Neuromuscular fatigueand recovery in elite female handball players, Scandinavian Journal of Medicine and Science in Sports, 16 (2006) 276273.

https://doi.org/10.1111/j.1600-0838.2005.00474.x

[10] N. Rogulj, N. Foretić, V. Srhoj, M. Čavala, V. Papić, Uticaj nekih motoričkih sposobnosti na brzinu lopte kod udarca u rukometu. [In Serbian], Acta Kinesiologica, 1(2) (2007) 71-75.

[11] B. Serrien, R. Clijsen, J. Blondeel, M. Goossens, J.P. Baeyens, Differences in ball speed and three-dimensional kinematics between male and female handball players during a standing throw with run-up, BSM Sports Science, Medicine \& Rehabilitation, 18 (2015) 4-12.

https://dx.doi.org/10.1186\%2Fs13102-0150021-x

[12] M. Marfell-Jones, T. Olds, A.Stew, L. Carter, International Standards for Anthropometric Assessment. Australia: The International Society for the Advancement of Kinanthropometry. (2006).

[13] N. Foretić, O. Uljević, A. Prižmić, Some metric characteristic of tests to assess ball speed during overarm throw performance, SportLogia, 6(2) (2010) 59-64.

http://dx.doi.org/10.5550/sgia.1002059

[14] A. Yapici, M. Ozkol, B. Ozçaldıran, M. Ergun, The relationship between throwing velocity with and without leg movements and isokinetic muscle strength in elite water polo players, European Journal of Physical Education and Sport Science, 3(1) (2017) 42-51.

https://doi.org/10.5281/zenodo.266161

[15] Rules of the handball game from 2016. www.zrsizp.rh

[16] N. Kurelić, K. Momirović, M. Stojanović, Ž. Radojević, N. Viskić-Štalec, Structure and development of morphological and motor dimensions of youth. [In Serbian]. Beograd; Institute for Scientific Research. Faculty of Physical Education. (1975).

[17] M. Vukotić, The level of morphological characteristics, motor and functional abilities of athletes of different sports orientation. [In Serbian]. Unpublished master's thesis. Nikšić: Faculty of Sports and Physical Education. (2010).
[18] W. D. Mcleod, S. C. Hunter, B. Etchison, Performance measurement and Percent body fat in high-school. American Journal of Sports Medicine, 11 (1983) 390-397.

https://doi.org/10.1177/036354658301100603

[19] T. J. Gabbett, Science of Rugby league football, a review, Journal of Sports Science, 23 (2005) 961-976 https://doi.org/10.1080/02640410400023381

\section{Acknowledgement}

NIL.

\section{Funding}

This study was not funded by any grant

\section{Conflict of interest}

The authors declare that they have no actual or potential conflict of interest, including financial, personal or other relationships with people or organizations that could have inappropriately influenced this work.

\section{Informed consent}

All participants gave written informed consent to participate in this study.

\section{About The License}

(C) The author(s) 2020. The text of this article is open access and licensed under a Creative Commons Attribution 4.0 International License 